\title{
The Enlightened Religion of Robert Clayton
}

\author{
C. D. A. LEIGHTON \\ (Bilkent University, Ankara)
}

In 1756 the apologist for the Irish Catholics, Charles O'Conor of Belanagare, declared himself fortunate to be living in an age which could boast thinkers

like a BERKLEY [sic] or a CLAYTON ... who ... take the Lead in human Knowledge; and who, had they the direction of human Affairs, would make the World vastly more wise, and consequently more happy, than hitherto it hath been known to be.'

This brief eulogy with its juxtapositioning of Clayton's name with that of the propounder of theistic immaterialism might be taken as an indication that the former was accorded a contemporary respect which has since been quite forgotten. If it is, the point needs much qualification. In fact, the bishop of Clogher's reputation as a scholar was but poor among contemporaries. When his first substantial work of learning appeared in 1747 , it was not believed to be his own. ${ }^{2}$ This effort did not, apparently, impress Thomas Sherlock. When Clayton's most famous, or rather infamous work, An Essay on Spirit ${ }^{3}$ appeared a few years later, Bishop Sherlock complained that such a 'trifling slight man' should venture into the most turbulent theological area of the age. ${ }^{4}$ Even O'Conor hardly believed what he said of Clayton. His compliment to Berkeley came because he wanted to make use of the bishop's view that the penal laws were economically disadvantageous. Similarly he wanted to make use of Clayton's whig opinions on the matter of toleration in general, ${ }^{5}$ thus

' [Charles O'Conor], The Principles of the Roman Catholics Exhibited in Some Useful Observations on a Pamphlet Entitled 'Plain Matters of Fact Humbly Recommended to the Consideration of the Roman Catholics of Ireland' (Dublin 1756) 8.

2 Andrew Kippis et al., eds, Biographia Britannica: or, the Lives of the Most Eminent Persons who have Flourished in Great Britain and Ireland ... (2nd ed., 5 vols., London 1778-93) III, 621.

'The attribution of this work to Clayton has, on very feeble grounds, been questioned. The matter is discussed in a note at the end of this study.

${ }^{4}$ Quoted by Mary Delany in a letter to Anne Dewes, 11 April 1752, A. Day, ed., Letters from Georgian Ireland: the Correspondence of Mary Delany 173I-68 (Belfast 1991) 93.

' These were expressed in the pamphlet to which O'Conor was replying. [Robert Clayton], A Few Plain Matters of Fact Humbly Recommended to the Consideration of the Roman Catholics of Ireland (Dublin 1756). 
suggesting that Catholics now shared the enlightened views which could make possible their integration into the Hanovarian state. Had he not been writing anonymously and obstensibly, if deliberately unconvincingly, in the persona of a Protestant, ${ }^{6}$ he would certainly not have wished to lavish praise on a profoundly anti-Catholic writer. Nor would he, an orthodox Catholic, have been inclined to commend a clergyman whose deviations from a common Christian creed had rendered him odious even to his own co-religionists.

Still, O'Conor's remarks were flattery which he hoped would be believed, not mockery. In fact, his own age did perceive Clayton as occupying, in Ireland, a place among the most notable of those who advanced the disturbing opnions which emerged from the ferment of thought in late Stuart and early Hanoverian Britain. It no doubt appeared to some contemporaries that by joining his name to Clayton's, O'Conor was overpraising Berkeley, who 'became a joke among the wits of the time for his philosophy and his failed Bermuda plan'. ${ }^{7}$ Even if not thought by his contemporaries to have an especially distinguished mind, Clayton was regarded as a competent articulator of important intellectual positions of the age. It was as such that he was apparently attacked, in the characters of Dechaine and Cunningham, by one of eighteenth-century Irish Anglicanism's best thinkers, Philip Skelton. ${ }^{8}$ It is as such that he has been chosen for attention in this study. It can be acknowledged that Clayton lacked intellectual stature and originality. It is this which renders him interesting. The less-gifted thinker is the more revealing depictor of the mind of the period and it is that which is the primary concern of the historian. This study is concerned far less with Clayton, than with his heterodox religion, the Arianism for which he was chiefly noted. The concern is with this as a historical phenomenon, and its origins as such, rather than as an intellectual position, or series of related positions, the relationships of which are to be traced by the reconstruction and re-exposition of philosophical and theological arguments. The former interest is answered better by consideration of a lesser writer, whose views require less patient and deep probing.

' O'Conor's argumentation in this literature and his use of anonymity and assumption of a Protestant persona are discussed in C. D. A. Leighton, Catholicism in a Protestant Kingdom: a Study of the Irish Ancien Regime (London 1994) 102-4.

${ }^{7}$ R. H. Popkin, ed., Millenarianism and Messianism in English Literature and Thought 1650-1800 (Leiden and New York 1988) 7.

" See David Berman's introduction to the reprint (2 vols, Bristol and Tokyo 1990) of Skelton's Ophiomaches: or Deism Revealed, xi-xiii. Of course, Clayton loomed large in Skelton's mind, in part, because he was his ordinary. 
Were one inclined to defend Clayton, one might point out that the dismissive or condescending assessments of his contemporaries were, in some measure, the product of prejudices. Andrew Kippis, in his brief account of Clayton's life and work, pointed, with considerable understatement, to one source of distortion of judgement among contemporaries, for whom 'the character of the scholar was lost in that of the gentleman'. Much of Clayton's life as a churchman was apparently devoted to the pursuit of preferment. In this he was preeminently successful. Through the influence of his relative, Lady Sundon, and of Samuel Clarke, whom he took care to cultivate, ${ }^{9}$ Queen Caroline was persuaded to obtain for him the see of Killala in 1730. In 1735 the queen's favour brought him Cork. It was due to the king's good will that in $\mathbf{1 7 4 5}$ he came into possession of Clogher, the second best bishopric in Ireland. ${ }^{10}$ A saddened nineteenth-century clergyman, when preparing a memoir of Clayton, observed 'little recorded of the Bishop, as a bishop, in any of his three dioceses'." The delightful letter writer and friend of the Claytons, Mary Delany, recorded visits by the bishop to Killala and Kilmore and left the distinct impression that, on those occasions, pastoral concern was rather lost in the pursuit of rural recreation. ${ }^{12}$

If Clayton showed little enthusiasm for the duties his preferments brought him, the increases in income they also brought were, despite his possesison of considerable estates in Lancashire, no doubt welcome. It was probably Katherine Clayton, the bishop's wife, whose character demanded the splendid state in which the couple lived. '[T]he Bishop loves to please and indulge her,' Mrs Delany told her sister, 'and is himself no way averse to the magnificence of life.' 13 The house built for them on Dublin's St. Stephen's Green, a year or so after the translation to Cork, set the style of the metropolitan palaces of the greater Irish noblemen in the city's architectural golden age. ${ }^{14}$ This and the fine country house, St Woolstan's, some miles west of the city provided the setting for an elegance of life which fully matched that of the rest of an élite, now recalled chiefly on account of that elegance.

${ }^{9}$ Kippis et al., eds., Biographia Britannica, III, 621.

10 P. Langford, A Polite and Commercial People: England 1727-45 (Oxford and New York 1989) 239.

"Robert Clayton, Bishop Clayton on the Nicene and Athanasian Creeds. Republished, with a memoir, by a vicar of the Church of Ireland (Dublin 1876) 31 .

${ }_{12}$ Day, ed., Letters from Georgian Ireland, 122-9 and 136-9.

13 Mary Delany to Anne Dewes, 8 Feb. 1746, ibid., 89.

${ }_{14}$ N. Sheaff, Iveagh House: an historical description (Dublin 1978) 17. A wellillustrated description is given 27-45. 
It was the pursuit of preferment, 'magnificence of life' and, if Laetitia Pilkington's disclosures are indeed about Clayton and if that notorious clerical wife and blackmailer is to be believed, the pursuit also of sexual gratification, ${ }^{15}$ which were the concerns which appeared to be uppermost in the bishop's life. That he should engage in scholarship at all seemed surprising; and if the conclusions he came to in his scholarly endeavours were repugnant, the causes for surprise became justifications for dismissing them. Certainly his views, or more accurately the extreme to which he took them, made Clayton a detested figure to very many. His death, the earl of Cork opined, came at 'a lucky time for his earthly welfare. The people were enraged against him to to a sanguinary degree. He might have fallen victim to the impious rabble'. ${ }^{16}$ Clayton had courted such unpopularity since 1750, when the Essay on Spirit had raised a storm of tracts. ${ }^{17}$ William Warburton memorably dismissed it as being 'made up out of the rubbish of old heresies; of a much ranker cast than common Arianism'. ${ }^{18}$ The bishop was careful to avoid acknowledgement of the anonymously published work as his own. When he next seriously offended orthodox opinion, in 1756, with a call in the House of Lords for the removal of the Nicene and Athanasian Creeds from the Church of Ireland's liturgy, he was again cautious, and asked the peers 'to observe, that I do not take upon me to say, that the Doctrine contained in the Athanasian Creed is false; I only say, it is not plainly and clearly revealed.' ${ }^{19}$ When, however, in 1757, he was foolish enough to repeat the views expressed in the Essay on

${ }^{4}$ Mrs Letitia Pilkington, Memoirs of .... Wife to the Rev. Mr. Matthew Pilkington (2nd ed., 2 vols., Dublin 1748-49) 245-9 and 268-9. The second of these passages, where she accuses the B...p of C... of meanness and the use of prostitutes certainly refers to Clayton, who was, as the passage indicates, her son's god-father. Cf. John Carteret Pilkington, The Life of ..., Son to the Reverend Mr. Matthew Pilkington and the Celebrated Mrs. Laetitia Pilkington ... (Dublin 1762) 6. The Irish bishop who is accused of meanness and sexual promiscuity on a grand scale in the first passage, is addressed as 'my little good lord Cardinal'. In his own intimate social circle, with which Mrs. Pilkington - before her adultery and divorce - was acquainted, Clayton was referred to as 'the cardinal'. See Mary Delany to Anne Dewes, 28 Dec. 1751, Day, op. cit., 92.

${ }_{16}$ John Boyle, earl of Cork, to Rev. W. Duncombe, 11 March 1758, quoted in Trinity College, Dublin, MS 1142, p. 124.

" Listings of these tracts can be found in A. R. Winnett, 'An Irish Heretic Bishop: Robert Clayton of Clogher', D. Baker, ed., Schism, Heresy and Religious Protest: Papers Read at the Tenth Summer Meeting and the Eleventh Winter Meeting of the Ecclesiastical History Society. Studies in Church History XI (Cambridge 1972) 311 21, 319-21 and in T.C.D., MS 1142, pp 66-81.

${ }^{1 *}$ William Warburton to Richard Hurd, 18 Nov. 1751, quoted in T.C.D., MS 1142 , p. 82 .

${ }_{19}$ [Robert Clayton], The Bishop of Clogher's Speech, Made in the House of Lords in Ireland ... on Monday, February 2, 1756 (London 1757) 22. 
Spirit under his own name in the third part of his Vindication of the Histories of the Old and New Testament, nothing could save him and he was threatened with the loss of his bishopric. Only his death, in February 1758, prevented this disgrace.

In truth, though, it was not merely that Clayton professed Arianism, but rather that he professed it when the once widespread heresy had been, for some years, in decline, which ensured that there was a decided lack of praise for his scholarship in upholding it. The revival in the British Isles of the doctrinal positions which had torn apart fourth-century Christianity came as a continuation of the trinitarian controversy of the $1690 \mathrm{~s} .^{20}$ By 1708 , the Cambridge divine, William Whiston, had reached the conclusion that both scripture and the apostolic church taught Arius's doctrines and in 1711 published his findings in the four volumes of Primitive Christianity Reviv'd. The following year, Samuel Clarke published his more circumspect and more important Scripture Doctrine of the Trinity. Clarke's antiTrinitarianism had a philosophical foundation and had already been briefly expressed in his Boyle lectures, A Demonstration of the Being and Attributes of God. ${ }^{21}$ However, the later work took a different tack. Its methodology, by which, like John Locke, Clarke spoke only of scripture and avoided relating this discussion to credal formulations in itself communicated one of the fundamentals of his, and all later Arians' religious position. Of course, such principled hostility to creeds had its advantage in preventing them from fulfilling their function in his own case: with only a little dishonesty, he managed to escape condemnation. ${ }^{22}$ Whiston, a man of uncompromising honesty, soon found himself outside the Church of England, making a living as best he could. Clarke's later life, as rector of St. James's, Westminster, and as patron of like-minded divines, such as Clayton and John Jackson, ${ }^{23}$ indicated the capacity of Arianism to thrive within the established church. Over the following years it was fashionable.

${ }^{20}$ J. A. I. Champion, The Pillars of Priestcraft Shaken: the Church of England and its Enemies 1660-1730 (Cambridge 1992) ch. 4, gives the best understanding of this. See also J. Redwood, Reason, Ridicule and Religion: the Age of Enlightenment in England 1660-1750 (London 1976) 156-65. J. H. Colligan, The Arian Movement in England (Manchester 1913) ch. 2, will furnish the names of many of the important writers and their tracts.

${ }^{21}$ J. P. Ferguson, An Eighteenth-Century Heretic: Dr. Samuel Clarke (Kineton, Warks. 1976) 47. L. Stewart, 'Samuel Clarke, Newtonianism, and the Factions of Post-Revolutionary England', Journal of the History of Ideas XLII (1981) 53-72.

${ }^{22}$ Ferguson, op. cit., chs 5-7.

${ }^{23}$ For Jackson, see R. W. Greaves, 'Fathers and Heretics in Eighteenth-Century Leicester', A. Whiteman et al., eds., Statesmen, Scholars and Merchants: Essays in Eighteenth-Century History presented to Dame Lucy Sutherland (Oxford 1973) 65-80. 
It is probably true, as Jeremy Goring and Roger Thomas claimed, that Arianism is to be regarded as chiefly of Anglican provenance. ${ }^{24}$ That protracted political attack on the status of the Church of England which characterised the first few decades of Hanoverian rule "came principally ... from the heterodox in response to priestly orthodoxy' 25 and it was Arianism which constituted the most fashionable form of heterodoxy. Be this as it may, it is the Presbyterian history of the period which speaks most explicitly about Arianism. In 1719, at Salters' Hall, the London Dissenters, Baptists and Independents as well as Presbyterians, split over a statement about the doctrine of the Trinity, required of them because of the appearance of Arianism among ordinands in Devon. It was the Presbyterian body which suffered most, thereafter fragmenting and, over the years, declining into near invisibility. ${ }^{26}$ It fell to Scots to restore English Presbyterianism in the following century. When the Toleration Act of 1719 had been secured, Arianism made an appearance among Irish Presbyterians and a bitter dispute ensued. With an established structure of church courts lacking to their English coreligionists, the Ulster Presbyterians had also authority, both to lose and wield in the face of an Arian threat and thus survived their troubles much better. In 1725 the Arians and their allies were, for the moment, corralled in the Presbytery of Antrim and in the following year the members of that body were excluded from the Synod of Ulster and its inferior courts. ${ }^{27}$ In Scotland, the public fast enjoined by the General Assembly of 1725 'to preserve us in this land from the danger of Deism and the Arian heresy' ${ }^{28}$ was less than wholly successful. When John Simson of Glasgow University was accused of Arianism, the case dominated the nation as well as the judicatories of the Kirk until 1729. Fearing schism, the General Assembly

${ }^{24}$ C. G. Bolam et al., The English Presbyterians: from Elizabethan Puritanism to Modern Unitarianism (London 1968) 22 and 150. This view was aired at the time by the Scottish ecclesiastical historian, Robert Wodrow. He, though, was probably predisposed to see the spread of corruptions among the adherents of prelacy and Erastianism. See Robert Wodrow to Cotton Mather, 9 Aug. 1725, T. McCrie, ed., The Correspondence of the Rev. Robert Wodrow, Minister of Eastwood ( 3 vols, Edinburgh 1842-3) III, 222-5.

${ }_{25}$ J. C. D. Clark, English Society 1688-1832: Ideology, Social Structure and Political Practice During the Ancien Regime (Cambridge 1985) 299-307.

${ }^{26}$ Bolam et al., op. cit., 17-28 and 130-74.

2- P. Brooke, Ulster Presbyterianism: the Historical Perspective 1610-1970 (Dublin and New York 1987) 46-53 and 72-92. A fuller narrative is provided in J. S. Reid, History of the Presbyterian Church in Ireland (I and II, 4th ed., III, 3rd ed., Belfast 1867) ch. 25.

${ }^{28}$ Quoted in Robert Wodrow to William Livingston, 28 June 1725, McCrie, ed., op. cit., III, 211-12. 
treated Simson mildly and thus gave more zealous Calvinists grounds for their establishment of the Secession Church in 1733. ${ }^{29}$

However, well before mid-century this Arian storm seemed to have passed for good. In the arena of serious Anglican theology it had suffered near fatal blows at the hands of Daniel Waterland in the 1720 s, as related Deist ideas had at the hands of Bishop Joseph Butler in the following decade. ${ }^{30}$ Political support for the heterodox was less forthcoming too: the court of George II, despite the apparent inclinations of the queen, was less disposed to support them that the court of George I had been. ${ }^{31}$ In the country, the clergy showed less anxiety. As late as the mid-1760s, the Dundee minister, John Willison, a friend to the Seceders and not one to miss evidences of backslidings and corruptions, was able to look back calmly at the Simson case and praise the moderation of the Assembly of the time. What had come of the matter was only a great corpus of orthodox trinitarian writing, 'so well written, we need add nothing, but join our testimony therewith, and pray that Arianism may never more set up its head in this land. Amen.' ${ }^{32}$ Clayton had the misfortune not to have noticed that the world had moved on. When he began to publish seriously, after obtaining Clogher, the views he expressed were fundamentally those which had been fashionable and had served him well when he was a young fellow of Trinity College, Dublin, looking for preferment.

One better informed than John Willison might, by 1765 , have been less satisfied that anti-Trinitarianism was a thing of the past. In 1759, Nathaniel Lardner, the best scholar English Dissent produced in the eighteenth century, published for the first time his Letter Written in the Year 1730, Concerning ... the Logos ... ${ }^{33}$ He might have had good reason to judge that the time for publication of this attack on Arianism (with an appended criticism of Clayton's views) from the more extreme Socinian position was 'fitly chosen'. There was certainly interest beginning to be shown in Socinianism in some acade-

${ }^{29}$ R. H. Story, ed., The Church of Scotland, Past and Present ... (6 vols, London 1890) III, 632-9 and 651-3. H. F. Henderson, The Religious Controversies of Scotland (Edinburgh 1905) ch. 1. C. G. McCrie, The Church of Scotland: her Divisions and her Reunions (Edinburgh 1901) ch. 3.

${ }^{30}$ For Butler see D. Brown, 'Butler and Deism', C. Cunliffe, ed., Joseph Butler's Moral and Religious Thought: Tercentenary Essays (Oxford 1992) 7-28.

"Langford, A Polite and Commercial People, 239-40.

${ }^{32}$ John Willison, A Fair and Impartial Testimony, Essayed in the Name of a Number of Ministers, Elders, and Christian People of the Church of Scotland (Glasgow 1765) 64-66.

${ }^{37}$ Nathaniel Lardner, The Works of ... With a Life by Dr. Kippis (10 vols, London 1838) X, 73-185. 
mic circles within the establishment. ${ }^{34}$ Arianism was not, in fact, dead. It lived on, now clearly subordinate to the more fashionable Socinianism, in a more general non-Trinitarianism, put forward by writers who, often holding benefices within the establishment, were usually less than anxious to let their doctrinal position be easily defined. ${ }^{35}$ Among Irish Presbyterians, however, this loss of identity did not occur. Here Arianism had survived in the Presbyteries of Antrim and Munster, and was not without many adherents in the Synod of Ulster too. In the 1820s both orthodox and heterodox judged that they had the times with them. On the approach of conflict, the latter were rallied with clear statements of what adherence to their admirable Arian tradition meant. ${ }^{36}$ In the battle in the Synod of Ulster, however, victory went to Henry Cooke and that body was purged of Arianism. ${ }^{37}$ These Arians do not appear to have had any obligation to Clayton. His mere Irishness was hardly enough rescue this haughty prelate from the obscurity into which he had fallen more than half a century after his death, least of all among those who, whatever their doctrine, continued to identify with the Presbyterian body.

The decline of Arianism and the rise of Socinianism and its absorption of Arian strands of thought deprived Clayton of disciples and a measure of praise as a scholar, which, had he written earlier, he might well have received. However, his mere heterodoxy was enough to commend him to one Socinian, Andrew Kippis, whose remarks, it was noted a century later, became 'the basis, and indeed the main authority for all that is elsewhere told of the Bishop'. ${ }^{38}$ This was somewhat unfortunate for Clayton's posthumous reputation. For although Kippis was willing to say that the bishop 'was a man of a great capacity ... and of extensive learning', as a Socinian he disliked Clayton's Arian conclusions and thus questioned 'the accuracy of his

${ }^{34}$ Clark, English Society, 311-15.

"For a brief exemplification, in this case from Scotland, of the difficulties the orthodox faced in accusing with accuracy, see A. McNair, Scots Theology in the Eighteenth Century (London [1928]) 119-20.

${ }^{36}$ William Bruce, Sermons on the Study of the Bible, and in the Doctrines of Christianity ... (Belfast 1824). To this explicit and particularly clear exposition of Arian doctrine, Bruce prefixed an 'epistle dedicatory' to his own Belfast congregation, which was apparently, like Bruce himself, conscious of the need to uphold their doctrines in the face of the newer Socinian ones. See pp i-iii. There clearly was, however, Socinian influence on some Ulster Presbyterians described as Arian. See Brooke, Ulster Presbyterianism, 148-9, and John Paul, Works of the Late Rev. ... of Carrickfergus (Belfast 1855) 485.

${ }^{37}$ R. F. Holmes, Henry Cooke (Belfast and Ottawa 1981) chs 2 and 3. Brooke, op. cit., ch. 7.

${ }^{38}$ T. C. D., MS 11142, p. 49. 
judgment'. This failing he attributed to 'the liveliness of his fancy', which carried him too far 'into the regions of conjecture'. ${ }^{39}$ This liveliness of fancy was only too apparent to those who noted, probably from Warburton's often repeated remarks, that Clayton had identified Christ with the Archangel Michael and the Holy Spirit with Gabriel. ${ }^{40}$ The suggestion of eccentricity was, though, hardly fair. Clayton's views on this matter were not so singular. Very similar ones had been put forward in the 1720 s by the scholarly biblical commentator, James Pierce, one of the ministers involved in the controversy which boiled over at Salters' Hall, ${ }^{41}$ and Lardner depicted these as not untypical of Arian views in general. ${ }^{42}$ Nor was this unjustified. As a later Irish anti-Arian, John Paul of Carrickfergus, made clear, if the Socinian option of holding Christ to be mere man was rejected without accepting him to be summus Deus, then his nature could only be that of a 'super-angelic being' ${ }^{43}$ It is true that Clayton differed from writers like Pierce in presentation, in that his emphasis appeared to rest on the expounding of an angelology rather than on his christological statements. Clayton set out what he intended to assert at the beginning of the work that was to be his final undoing:

that we ought to consider this whole Universe as one Community of Spirits, which may all contribute to compose one grand System, with God at their Head; in which an infinite Number and Variety of Beings, beside Mankind may be concerned, ... [and this] we must take into Account, before we can frame any tolerable Notion of the Administration of God's Providence in the Jewish or Christian Dispensations; that is, either of the Fall of Man by the Temptation of Satan, or of the Redemption of Mankind by the Sufferings of the Messiah. ${ }^{44}$

What this approach indicated was Clayton's interest in the cosmologies of the Cambridge Platonists, which sought to ground Newtonian science in a spiritual metaphysics. ${ }^{45}$ It was, in the end of course, a mechanistic interpretation of Newton which prevailed.

${ }^{39}$ Kippis et al., eds., Biographia Britannica, III, 627-8.

40 [Robert Clayton], An Essay on Spirit (Dublin 1750) 50-94.

${ }^{4}$ James Pierce, A Paraphrase and Notes on the Epistles of St. Paul to the Colossians, Philippians and Hebrews: After the Manner of Mr. Locke (London 1727). See especially, Col., 32-9, and Phil., 30-2.

+2 Lardner, Works, IX, 582-91.

43 Paul, Works, 408.

${ }^{44}$ Robert Clayton, A Vindication of the Histories of the Old and New Testament, Part III: Containing Some Observations on the Nature of Angels and the Scriptural Account of the Fall and Redemption of Mankind (Dublin 1757) 4-5.

${ }^{45}$ R. H. Popkin, 'The Spiritualistic Cosmologies of Henry Moore and Anne Conway', S. Hutton ed., Henry Moore (1614-1687): Tercentenary Studies (Dordrecht 1990) 97-114. 
However, Clayton was not singular in retaining an interest in Cambridge Platonists' spirit-filled universe and developing his theological views in the light of it. Probably the most interesting example is the Franco-Scottish scholar, Andrew Ramsay. ${ }^{46}$ As in his Arianism, so in the beliefs in which he grounded it, Clayton took his position in a line of thought which was certainly of diminished importance. However, this is not to allow Clayton to be dismissed as a mere anachronism. Traditions stemming from late Renaissance speculations were quite visible in the currents of thought of the European mainland's Enlightenment and Counter-Enlightenment, most notably in the the theosophical forms of Freemasonry which flourished in this milieu. ${ }^{47}$

Clayton's identification as an Enlightenment figure rests pre-eminently on his Arianism. Encountering, often apparently with surprise, this fourth-century heresy as a widespread phenomenon in eighteenth- and early nineteenth-century Britain, modern writers usually feel obliged to give some short definition. Lardner offers a contemporary one. Sifting through the variety of Arian views, he concluded: 'They all suppose the Word, or Son of God, to be a being distinct from God the Father, subordinate and inferior to him.' This did not adequately distinguish the Arian view from that of the Socinians, who, holding the Christ to be a mere glorified man, might have assented to this. The divergence, Lardner thus went on to point out, lay in the belief of the Arians in the pre-existence of the Logos and their assertion that 'our Saviour had not, properly, a human soul. But the Word ... supplied the place of a soul. ${ }^{48}$ Such definitions, though, do little to explain the late recrudescence of these beliefs or their contemporary significance. Why did they so pre-occupy such major figures in the history of nineteenth-century British religion as Henry Cooke and John Henry Newman, who ' $t$ ] hrough forty years of crisis and controversy ... indefatigably pursued Arianism as the key that unlocked the mysteries of his own mind and of the corrupt civilization around him.' $?^{49}$

${ }^{t 6}$ G. D. Henderson, Chevalter Ramsay (London 1952) ch. 18.

${ }^{47}$ C. McIntosh, The Rose Cross and the Age of Reason: Eighteenth-century Rosicrucianism in Central Europe and its Relationship to the Enlightenment (Leiden and New York 1992).

${ }^{48}$ Lardner, Works, IX, 584.

${ }^{49}$ R. Pattıson, The Great Dissent: John Henry Newman and the Liberal Heresy (Oxford and New York 1991) 103. 
The origins of neo-Arianism are best sought first in the religious history of the seventeenth century, in particular in that movement which Leszek Kolakowski called the 'second Reformation', the adherents of which 'accused the Protestant churches of not having gone far enough towards the original Protestant goals'. What in particular offended these 'non-confessional Christians' was the ceremonialism and insistence on credal formulation, 'which they saw as signs of religious decay'.$^{50}$ Such views readily united with those of anti-Trinitarians ${ }^{51}$ and also tended to lead, as has been shown in the case of the Dutch Collegiants, to adherence to the rationalism of the early Enlightenment. The step from the individual's enlightenment by the Holy Spirit to his enlightenment by reason was a slight one, as Graf Reventlow too pointed out in his remarkably wide-ranging study, probing as far back as the high middle ages, of what may certainly be called the same phenomena in England. ${ }^{52}$

In what, though, lay the mutual attraction between trinitarian heterodoxy, in particular Arian christology, and these currents of thought? The answer is to be found in the foundational role which, historically, christology played in the construction of Christian doctrine. At the appearance of Arianism in the early church, its theologians were 'driven to a realization that the deepest questions which face Christianity cannot be answered in purely biblical language, because the questions are about the meaning of biblical language itself.' ${ }^{53}$ It was thus at the appearance of Arianism that non-biblical credal formulations, determinative of all subsequent development, began to appear as the weapons of orthodoxy. To embrace Arianism in the eighteenth century did indeed mean to call for a more thoroughgoing reformation, in the usual early modern sense of calling for a return to the pristine; to a situation in which, with the fetters of creeds and confessions removed, Christian doctrine could be made anew. It was thus that most of the major disputes spoken of above, in

${ }^{\circ}$ Kolakowski's views are set out in his Chretiens, sans Eglise: la Conscience Religieuse et la Lien Confessionnel au XVIIe Siecle (Paris 1969). A convenient summary can be found in A. Fix, Prophecy and Reason: the Dutch Collegiants in the Early Enlightenment (Princeton, N.J. 1991) 48-51. The quotations in the text are taken from this.

s1 Ibid., ch. 6.

${ }^{52} \mathrm{H}$. Reventlow, Bibelautoritat und Geist der Moderne: die Bedeutung des Bibelsverstandnisses fur die geistesgeschichtliche und politische Entwicklung in England von der Reformation bis zur Aufklarung (Gottingen 1980). This is available in English translation as The Authority of the Bible and the Rise of the Modern World (London 1984).

${ }_{43}$ R. P. C. Hanson, The Search for the Christian Doctrine of God: the Arian Controversy (Edinburgh 1988) xxi. 
which contemporaries perceived Arianism to be the real issue, were fought out as disputes about subscription to credal formulations, the Anglican Articles or the Westminster Confession. In brief, to be an Arian was to embrace 'the antidogmatic principle', to use the definition of liberalism given by Newman, for whom ' $t$ ] he father of liberalism was Arius'. ${ }^{54}$

In Clarke, near the beginnings of the neo-Arian controversy, the emphasis in the call to reformation lay on the decay which credal formulation in the Protestant churches indicated. ${ }^{55}$ Clayton, however, reflected a growing belief in progress and struck a more positive note. Explaining his beliefs to the unreceptive Irish peers, he pointed out the inadequacy of the sixteenth-century reformation, though he judged the reformers prudent in not making 'too great an Alteration all at once'. Since the eighteenth century was 'undoubtedly a more enlightened Age, than that in which the Nicene Council was assembled', it fell to Clayton and his contemporaries to perceive its fault, remove its credal shackles and allow theology to make progress with the other sciences, along the lines laid down by the great figures of the early English Enlightenment. ${ }^{56}$

To say, as Clayton suggests here, that Arianism opened the floodgates to an Enlightenment re-interpretation of Christianity is true, but does not exhaust what is to be said of the relationship between Arianism and the Enlightenment. Indeed, writers who have occasion to mention neo-Arianism generally advert, not to its acceptance of, but to its dependence on Enlightenment rationalism. ${ }^{57}$ This relationship has been readily perceived, with attention focussed on Arianism's christological and trinitarian assertions, ${ }^{58}$ rather than on the anti-confessional consequences of them. If the English

\footnotetext{
${ }_{4}$ Pattison, op. cit., 101. In fact, it is an acquaintance with the writings of Newman which will give by far the most profound understanding of the significance of neoArianism. Conversely, in view of his 'Arian obsession' (ibid., 103), a study of neoArianism offers the best background for an understanding of Newman. Regrettably, Newman obscured this from his commentators by a preference for speaking ostensibly, much of the time, of the fourth-century phenomenon. The significance of Arianism for Newman has been explored by Pattison; but the study lacks an understanding of the importance of Arianism in the theological conflicts of eighteenth- and early nineteenth-century Protestant Britain and thus in large measure isolates Newman from his theological tradition. Much the same may be said of Stephen Thomas's Newman and Heresy: the Anglican Years (Cambridge 1991).

"s Samuel Clarke, The Works of ... (5 vols, London 1738) IV, iii-viii.

st [Clayton], Speech ... in the House of Lords, 8, 14 and 15-17. See also Essay on Spirit, xix-xxii, and Vindication, III, 36.

${ }^{47}$ See, for example, Holmes, Henry Cooke, p. 24.

${ }^{98}$ It is not contradictory to speak of Arian 'trinitarian assertions', in that Arians did speak of a Trinity, though generally ascribing to it no more than a moral unity.
} 
Enlightenment is remembered as an epistemological assertion, preeminently concerned with '[e]levating the claims of reason and logic' and showing 'contemporaries that theological mystery was wrong', ${ }^{59}$ its pervasive influence on Arian writers is never far to seek.

In Clayton there is a nominal denial of the necessary preliminary of this assertion of reason. He protests much against writers, notably Bolingbroke, who separate faith and reason. Such an approach, he maintains, must issue in the fulfilment of the desire either of the Deist to overthrow religion or of the Papist to overthrow reason. In reality, however, Clayton, like other neo-Arians, had no place in his thought for faith, as Christianity had traditionally understood it. Its origins in grace and its character as an act of will were removed and its only remaining component was reason. Faith for Clayton was merely rational belief, founded on authority - that of revelation - as opposed to investigation. ${ }^{60}$ Thus, taking up a debate which had become explicit in the $1730 \mathrm{~s},{ }^{61}$ he declared in favour of heresy generally. At least it was not to be condemned, for no moral fault could attach to a mere 'Error ... of the Judgment'. And then, it might be no error, but a useful call to reform. ${ }^{62}$ Since faith, for which the word 'belief' was preferred, was reduced to an act of reason, it was improper to speak of believing in a mystery defined simply as an area inaccessible to reason. Concluding, with a quite amazing disregard of the complexity of the argument he was engaged in, that not only the Godhead itself but also Christian teaching on it constituted such a mystery, Clayton judged himself at liberty to reject the latter. ${ }^{63}$

In the past, historians have shown a marked unwillingness to permit the Enlightenment, with its parameters and characteristics set by European historiography, to be an indigenously English phenomenon: the particularity of England would not allow reference to an English Enlightenment any more than it would to an English ancien regime. ${ }^{64}$ At the present, however, it appears quite possible to accept Arthur Wilson's claim, rather too cautiously advanced as a 'startling'

${ }^{59}$ Champion, Priestcraft Shaken, 10.

${ }^{60}$ Robert Clayton, A Vindication of the Histories of the Old and New Testament, Part II: Wherein the Mosaical History of the Creation and Deluge is Philosophically Explained ... (Dublin 1754) 53-61.

61 Redwood, Reason, Ridicule and Religion, 23-4.

${ }_{62}$ [Clayton], Essay on Spirit, xix-xlviii, xxviii. Cf. his Vindication, III, 33-5.

${ }^{63}$ Ibid., 13-28.

${ }^{64}$ Continuing hesitation over the use of the term is indicated by Geoffrey Holmes in his synthesis, The Making of a Great Power: late Stuart and early Georgian Britain 1660-1722 (London and New York 1993) ch. 24. 
hypothesis, that ' $[\mathrm{t}]$ he Enlightenment came first to England'. ${ }^{65}$ It would probably, though, be best to re-express the idea contained in it as a claim that England's most notable contribution to the Enlightenment came in its early phases. It is possible not only to defend the assertion of the existence of an English Enlightenment, but an integrated perception of its content can be offered also. John Redwood has spoken of the way in which all this period of ferment's 'debates about politics, natural philosophy, theological doctrine, and the social structure were all part of one far greater debate', which he holds to have been driven by fear in the face of the contemporary attack on religion. ${ }^{66}$ Intellectual positions can be placed on a continuum of argumentation, about diverse subject matter, between the most extreme anti-religious stance and orthodox Christianity, the positions revealing various degrees of willingness to make concession to criticism of Christianity and, usually, provoking hostility from two sides. Important modification of this view comes from Justin Champion, who accepts that the 'greater debate' is indeed concerned with the assault on religion, but emphasises that religion was not merely a series of propositions, but a complex institution permeating society. This both anchors the English Enlightenment in English socio-political reality and shows it to have been concerned with the question of 'who or what institution held the authoritative interpretation of truth' and thus concerned with 'the distribution of authority in society'. ${ }^{67}$

It is such perceptions of the English Enlightenment which allow the most satisfactory understanding of its relationship to neoArianism and the significance of that phenomenon. For to have said that Arianism encouraged adherence to Enlightenment ideas, though at the same time was a product of them, is inadequate. The relationship was one to be thought of in the categories less of cause and effect, than of identification and this fact is related less to Arianism's christological and trinitarian statements, than to the rejection of credal formulation they inevitably involved. Because of this Arianism constituted the most important and prominent line of division in the argumentation which was the English Enlightenment: it marked the boundary beyond which Christianity and its opposing doctrines could not go and retain their integrity. Certainly there was

or A. M. Wilson, 'The Enlightenment Came First to England', S. B. Baxter, ed., England's Rıse to Greatness, 1660-1763 (Berkeley, Los Angeles, and London 1983) 1-28.

o6 Redwood, op. cit., 9-16.

${ }^{67}$ Champion, Priestcraft Shaken, 10 and 11. 
penetration on both sides of this boundary: the most orthodox were not immune from strands of thought we easily identify as characteristic of the Enlightenment and Arians and Socinians considered themselves champions of Christianity. Nevertheless, the frontier it was. The point is made by the assertions of the orthodox throughout the period of neo-Arianism's flourishing that if such trinitarian heresy was present, the religion of its adherents was not Christianity. ${ }^{68}$ It is more succintly made by the divergence of the careers of Clarke and Whiston, one within the church, the other outside it. It is more substantially made by the refusal of eighteenth-century ecclesiastical authorities to regard as warranting legal action any doctrinal deviation not relating to trinitarian doctrine. ${ }^{69}$

To assert the reality of this Arian boundary or more, to assert the pre-eminence of the Arian dispute over all the other disputes of the English Enlightenment, is, of course, to adopt a standpoint within the established churches of the period. For it was the orthodox who drew the boundary, verbally and in legal process. And it was from within the establishments and bodies that might have aspired to establishment that the Arianism on their boundaries loomed large enough to obscure the significance of other hostile sets of doctrines. It is understandable if the philosopher concerned with the English Enlightenment does not wish to adopt this position. However, the historian is bound to adopt as his own Bishop Clayton's definition of orthodoxy as the prevailing opinion of a place and time ${ }^{70}$ and recall a duty to give emphasis, an empathetic emphasis, to the normative of a period, if a distorted image of it is to be avoided. This point, it may be added parenthetically, should be recalled in considering the extent to which Arianism was the true motivation of the subscription controversies, chiefly that associated with the name of Salters' Hall and that in Ireland between 1719 and 1726. It is necessary, of course, to make clear that by no means all Non-subscribers were heterodox in their trinitarian beliefs. Further, it is difficult to assign a simple label to the complex of ideological, philosophical and theological beliefs which drove these conflicts. ${ }^{71}$ However, the mind of the period iden-

${ }^{6 *}$ See, for example, Charles Leslıe, The Socinian Controversy Discuss'd (London 1708) xxiii-xxxviii. The reference in the title to Socianism should not confuse, as Leslie was writing just before the appearance of the works of Whiston and Clarke, when Socianism and Arianism were not clearly distinguished. For a late example, see Paul, Works, 412-28.

${ }^{69}$ See, for example, McNair, Scots Theology, 989-8.

${ }^{70}$ [Clayton], Essay on Spirit, xxxii.

7 See A. W. G. Brown, 'A Theological Interpretation of the First Subscription Controversy (1719-1728)', J. M. L. Haire et al., Challenge and Conflict: Essays in Irish Presbyterian History and Doctrine (Antrım, 1981) 28-45. Here it is suggested 
tified those beliefs as Arian much more readily than as anything else and it seems ill-advised for the modern writer to adopt any other identification.

It should be emphasised here that the concern of the orthodox with the attack on credal formulation which Arianism involved, extended beyond zeal to defend Christianity's doctrinal structure. This, of course, was of primary importance among those who took seriously the doctrine of justification by faith, alone or not, and had not succumbed to the emerging conviction that human action was chiefly determined by interest rather than belief. Nevertheless, it should be noted that while Arianism involved rejection of credal formulation, rejection of credal formulation involved rejection of the ecclesiastical authority which was the origin and upholder of the formulae. To state the matter bluntly, to be an Arian meant to hold that individuals had a right to determine their own religious beliefs. ${ }^{72}$ And since, at least for the orthodox, states were founded on religious principles, this implied a right in individuals to determine their own political beliefs also. Arians, of course, were hardly inclined, at least for most of the eighteenth century, to draw such an offensive conclusion; but their opponents were not slow to point out the logic they perceived in their arguments. ${ }^{73}$ The eighteenth-century states' successful use of religion as their raison d'etre meant that any religious dissent posed some kind of political threat; but that posed by Arianism could look like anarchy.

The perception of the character of Arianism as a defence of Christianity which conceded too much to contrary positions gives one useful approach to the body of Clayton's writings. Clayton certainly thought of himself as an apologist for Christianity. It was in accord with, if not nessarily motivated by his adherence to the Arian form of the sola scriptura doctrine which excluded credal formulation, that he devoted his attention, in the first place, to what can be referred to as the defence of the historicity of scripture, though it

that the theological views of the Irish Non-subscribers are best denominated as Arminian. The same view is taken of the views of the English Non-subscribers by Jeremy Goring, in Bolam et al., English Presbyterians, 21-23. The distinction between Arminianism and other more extreme positions is not as easily drawn as these writers suggest. Isabel Rivers has recently shown well how Arminianism, as orthodox Calvinists never tired of reminding their readers, at least 'prepared the ground which made ... [later] developments possible'. Reason, Grace, and Sentiment: a Study of the Language of Religion and Ethics in England, 1660-1780 (2 vols, Cambridge 1991) I, 1.

${ }_{72}$ Brooke, Ulster Presbyterianism, 88-89.

${ }^{73}$ See, for example, John Malcome, Personal Persuasion No Foundation for Religious Obedience (Belfast 1729) 9-10. 
might be more precisely denominated. The task of defending scripture's historicity, he had long held, was the one of primary importance. In the early 1730 s he mocked Bishop Francis Hutchinson's not very academically fruitful defence of the historians of ancient Ireland, observing sarcastically that he was sure that 'by such Research [the bishop would] be able to confute Infidelity; and bring over Numbers of Converts to the belief of Revelation.' In the 1740s he took up the duty 'to vindicate the Divine History of Moses' which he reproached Hutchinson for neglecting. ${ }^{74}$ At least this was part of the purpose of his most substantial and scholarly work, The Chronology of the Hebrew Bible Vindicated. When he began to write the Essay on Spirit a few years later, he perhaps had the intention of taking another apologetic tack. Declaring the work to be a metaphysical treatise, he took up one of the major themes of the English Enlightenment, the existence and role of spirits in creation. ${ }^{75}$ But it was both metaphysics and scriptural studies that led him to the expression of his Arianism in this book, since its offensive angel christology was based on ingenious biblical exegesis. Apologetic based on scripure, rather than for scripture, was the task in Clayton's addresses to Jews. But in this field of endeavour also he was led to guarded, if clear, expression of Arianism, to convince his readers that Christians adhered to the doctrine of 'the Unity of the Godhead as strongly as Jews can possibly do' ${ }^{76}$ His apologetic of the mid to late $1750 \mathrm{~s}$, the Vindication of the Histories of the Old and New Testament, once again also began with the subject of biblical chronology, in which Bolingbroke had dabbled with Deistic intent; and once again, as already noted, the result was the expression of Arianism. Seen as a whole, Clayton's work is a reflection of his conviction, concisely stated in his last book, that trinitarianism constituted the great difficulty in winning converts to Christianity, and, in particular, the winning over of 'many thinking Persons from Deism'. ${ }^{77}$

For Clayton, as for many other neo-Arian writers, the rejection of ecclesiastical authority with which their doctrine was bound up constituted a fundamental element in their call for the renewal of the Reformation. Following out the main line of Protestant apologetic, which saw Popery as the product of the sinful advancement of

${ }^{74}$ [Robert Clayton], A Letter to the Right Reverend the Lord Bishop of [Down and Connor], Concerning his 'Defence of the Ancient Historians' (Dublin 1733) 5.

${ }^{75}$ Redwood, Reason, Ridicule and Religion, ch. i.

${ }^{76}$ [Robert Clayton], An Enquiry into the Time of the Coming of Messiah, and the Restoration of the Jews (London 1751), 41-44.

${ }^{77}$ Clayton, Vindication, III, 13-15. 
priestly power, ${ }^{78}$ they denounced all authoritative interpretation of scripture as the establishment of an 'infallible Rule or Guide ... such as the Roman Catholicks have ... errected the Pope into' ${ }^{79}$ Clayton appears to have been hardly conscious of the radical implications of this position. Probably with more naive hope than conviction, he claimed that his views could not "well give Offence to the Powers that be; there being a wide Difference ... between an Attempt to amend, and to overturn, an Establishment. ${ }^{80}$ All that he envisaged was an establishment, rendered comprehensive by its abandonment of creed, ${ }^{81}$ in which, if uninterpreted scripture could not provide decorous order, the state could. ${ }^{82}$

For those concerned to seek the origins of political radicalism in eighteenth-century religion, Clayton seems a fruitless source: by way of political assertion, nothing beyond commonplace, if zealous whiggery is to be observed. It might be remarked that whiggery was itself a religious enough phenomenon. It may also be said that attention ought to be paid to the implications, whether understood and stated or not, of religious positions. In other words, it needs to be recalled that in the ancien regime politics was always a religious matter and religion always in se political. However, even if attention is restricted to what is perceived at once as politically significant, church Arians such as Clayton deserve, despite the conventionality of their sentiments, some note. It was not alone those who had to justify separation from the establishment who developed claims for political liberties. ${ }^{87}$ If the claims made for freedoms for the elite Clayton called 'the thinking Part of Mankind' ${ }^{84}$ were not extensive little beyond freedom of speech and the press - they were made and with fervour. This worldly prelate's depiction of himself in his final tract as standing in the company of the heroic heretics, Socrates and Galileo, and again, his suggestion that refusal of preferment consti-

${ }^{78}$ Leighton, Protestant Kingdom, 49-51, explains the matter concisely.

${ }^{79}$ Robert Clayton, A Vindication of the Histories of the Old and New Testament [Part I]: in Answer to the late Lord Bolingbroke (4th ed., Dublin 1754) 44.

${ }^{80}$ Clayton, Vindication, III, 37-8.

${ }^{81}$ Comprehension of dissenters was Clayton's political justification for his Arian stance. See [Clayton], Speech ... in the House of Lords, 3 and 7. See also Historical Manuscripts Commission, Manuscripts of the Earl of Egmont: Diary of Viscount Percival Afterwards first earl of Egmont (3 vols., London 1920-23) III, 16-17.

${ }_{82}$ Robert [Clayton], The Religion of Labour: a Sermon Preached in Christ Church, Dublin (Dublin 1740) 18-19. See also Essay on Sptrit, xlviii.

${ }^{81}$ This relationship of religion and radicalısm is discussed in R. E. Richey, 'The Origins of British Radicalısm: the Changing Ratıonale for Dissent', EighteenthCentury Studies: an Interdisciplinary Journal, VII (1973-4) 179-92.

${ }^{* 4}$ Clayton, Vindication, III, 41. 
tuted an instrument of tyranny, are amusing. ${ }^{85}$ Yet they do serve as a reminder that the heterodox who were within the establishments did feel more immediately than those who were outside them the exercise of authority which occasioned pleas for freedoms.

When the importance and centrality of neo-Arianism in the English Enlightenment has been acknowledged, consideration of neo-Arianism provides the most striking confirmation of assertions of continuity between Puritanism and that Enlightenment. Even leaving aside the relationships established by traditional intellectual history, the study of which has tended to focus on the Cambridge Platonists, observation of the mere occurrence, without reference to its sources, of the intellectual phenomena of Puritanism in the later period, pointed to by Reventlow, is already persuasive.

What, though, are to be taken as the characteristic phenomena of Puritanism? Its identity within the Elizabethan and Jacobean church has sometimes been made markedly less distinct by modern writing's emphasis on the Calvinist consensus of the period. In response to this, attention has been directed to the character of Puritanism's Calvinist piety. The Puritans not only believed in predestination, election and assurance, as did the English church as a whole, but sought the experience of assurance in the circumstances of their own lives. ${ }^{86}$ In the concern - or sometimes anxiety - which brought about the search for God's salvific providences in daily life, is to be found the origins of the practical zeal for the programme of continuing reform of the church - from nation to parish - the existence of which remains an uncontested and measurable mark of the presence of Puritanism. More interestingly, modern writing has devoted much attention to the intensity of Puritan eschatological beliefs about the immanent overthrow of the Roman Anti-Christ. ${ }^{87}$

Zeal for a renewal of reform or, more precisely, of the Reformation in the church can be received as an uncontentious point of unity between Puritanism and neo-Arianism. But it may appear

${ }^{85}$ Ibid., 33-5 and 44-7.

${ }^{*}$ R. T. Kendall, Calvin and Englısh Calvinısm to 1649 (Oxford 1979). See esp. 1-13. See also P. G. Lake, 'Calvinısm and the Englısh Church 1570-1635', Past and Present, no. 114, (1987) 32-76.

${ }^{87}$ See, esp. W. M. Lamont, Godly Rule: Polttics and Religion 1603-60 (London 1969). W. Haller, Foxe's Book of Martyrs and the Elect Nation (London 1977). C. Z. Wiener, 'The Beleaguered Isle: a study of Elizabethan and early Jacobean ant1Catholicısm', Past and Present, no. 51 (1971) 27-62. 
exceptionable, or even perverse, to point to the depth of Puritanism's commitment to Calvinism as disclosing its character as a source of neo-Arianism, which has, on occasion, been confused with Arminianism. ${ }^{88}$ Clayton, with his fervent denunciation of 'the Mahometan and Calvinistical Doctrine of Predestination', certainly seems to conceal his Puritan antecedents very well. ${ }^{89}$ However, what should be noted is the immanentist supernaturalism, which was the necessary underpinning of the practical divinity by which Puritan identity has been asserted. The most precise intellectual threat to such belief at the end of the seventeenth century and in the early years of the eighteenth century came from the Deist rejection of a special, as opposed to a general providence. This preoccupied Whiston, who set about vindicating the manifestations of God's special providence recorded in scripture, most notably in his $\mathrm{New}$ Theory of the Earth of 1696 and the 1707 Boyle lectures, The Accomplishment of Scripture Prophecy. ${ }^{90}$ But surrounding the explicitly Deist argumentation there was, as already mentioned, a more general scepticism, which expressed itself chiefly in attacks on belief in the supernatural activity of subordinate spiritual beings.

The description given above of Clayton's works make it clear that he was an apologist not merely for Christianity, but for what may be called, though it may and will below be given a more precise name still, immanentist supernaturalism. It was not possible to defend the historicity of scripture without defending the notion of special providence and, as already said, his explicitly Arian statements followed on his exposition of the claim that '[a]ll Nature...seems to be animated, or alive; and the whole World to be replete with Spirits'. ${ }^{11}$ Moreover, Clayton can be seen taking up the precise topics that Whiston did. The manifestation in creation of an intervening God is the subject matter of the second part of his Vindication of the Histories of the Old and New Testament. He had already devoted much attention to scriptural prophecy and its fulfilment, the pre-eminent vindication of belief in a God actively involved in the world's history. For this was the theme of his two tracts addressed to Jews in 1751, as well as the Dissertation on Prophecy of 1749.

It should be observed that Enlightenment attacks had had an effect on the immanentist supernaturalism to which Clayton adhered: it

${ }^{8 x}$ See note 71 above.

${ }^{89}$ Clayton, Vindication, III, 12-13.

7) J. E. Force, William Whiston: Honest Newtonian (Cambridge 1985) chs 2, 3 and 5. Redwood, Reason, Ridicule and Religion, ch. 5, provides further background to Whiston's work.

${ }^{91}$ [Clayton], Essay on Spirit, 14. 
was a much diluted belief. God's hand was visible in human history to those who had understood the books of prophecy. Lesser supernatural phenomena, marking interventions by inferior spirits, were possible. In commenting on Deuteronomy XVIII, that most traditional of occasions for the discussion of magic, Clayton reached the conclusion that Pharaoh's magicians were indeed 'assisted ... by some invisible Beings'. But this he asserted only after pointing out that most of the magical practices to which reference is made in the scripture were impostures. Further, frequent occurrence of supernatural manifestations was safely confined to the 'early Ages of the World' ${ }^{92}$ The diminution, if not disappearance, of the miraculous at the end of the biblical era was important to Clayton. The miraculous had vindicated the authority of the apostles: its cessation indicated the lack of divine authority in those who now led the church and contradicted the claims of enthusiasts who claimed a personal inspiration. ${ }^{93}$

The extent to which Clayton lacked any real sense of the supernatural is revealed in his published correspondence with William Penn, the grandson of the famous champion of the Quakers. Their topic for debate was a familiar one between Quakers and churchmen, occasioned by the Quaker denial of the necessity of baptism by water. The bulk of the discussion consisted of the usual exchange of proof texts and interpretations of these texts, with a view to establishing which position was commanded. What becomes visible in this, however, is an underlying difference of outlook between the correspondents. Penn rejected the established church's practice because it did not appear to work any supernatural change, such as he looked for from a baptism, not of water, but of the Holy Ghost. Penn sought 'Divine Assistance; through whose secret Influence and operative Virtue a new Birth may be perfected, Mankind become a new Creature, and gain a Knowledge, which no human Science can give' ${ }^{94}$ Clayton, it seems, was hardly able to comprehend this. He wondered if the Quaker claim that the Christian should be 'baptised into the Virtue and Power of Christ ... [had] any Signification at all' ${ }^{9 \varsigma}$ He could accept the Quaker emphasis on interiority, but only by quite misunderstanding it to mean a belief that 'the moral Duties

${ }_{92}$ Robert [Clayton], The Chronology of the Hebrew Bible Vindicated (London 1747) 231-58, 353 and 254.

${ }_{97}$ [Clayton], Religion of Labour, 18-19.

${ }_{94}$ Robert [Clayton] and William Penn, Letters which Passed between the Right Reverend Robert, Lord Bishop of Cork, now Lord Bishop of Clogher, and William Penn, concerning Baptism (London 1756) 55.

95 Ibid., 69. 
of Religion [rather than cultic observance] make up the main and principal Parts of it'. ${ }^{96}$

Some more precision must now be given to the description of the religion Clayton espoused as an attenuated immanentist supernaturalism. Such a description does not reach the heart of the matter. In seeking the core of the bishop's religion, attention should be turned to his call for ongoing reform, which is to say, since the reform was to be a continuation of that of the sixteenth century, to his antiCatholicism. And this anti-Catholicism, like that of the Puritan era, consisted chiefly of a set of eschatological beliefs. In his re-articulation of the millenarian tradition of the Cambridge commentators Thomas Brightman and Joseph Mede, Clayton was by no means singular among Arians and Socinians. Newton's devotion to the investigation of biblical eschatology is now discussed, though his thought in this field is by no means fully investigated and its relationship to the rest of his work by no means fully comprehended. ${ }^{97}$ Whiston differed with Newton about the date of Second Coming, though they were substantially agreed about the method to be used in calculating it. ${ }^{98}$ At the other end of the century, Joseph Priestly was certainly not alone among the heterodox in having the conclusions he derived from his of the study of Daniel and Revelation confirmed by the revolutionary events in France. ${ }^{99}$

Clayton's devotion to the study of the Old Testament led him to a simple belief about the content of its message. The Hebrew scriptures existed 'to point out to them [the Jews] their Messiah, to establish a Set of Laws' and to provide motives for obeying these. ${ }^{100}$ In surveying the rest of his work, it becomes clear that the bishop did not think the Christian scriptures as a whole had any other substantial purposes. He explained to Penn, that the difference between Christian baptism and the baptism practised by the ancient Jews lay in the faith professed. The latter was baptism 'into the Belief of

96 Ibid., 37.

${ }^{47}$ R. H. Popkin, 'Newton as a Bible Scholar', J. E. Force and R. H. Popkin, Essays on the Context, Nature, and Influence of Isaac Newton's Theology (Dordrecht 1990) 103-18. See also A. Quinn 'On reading Newton apocalyptically', Popkin, ed., Millenarianism and Messianism, 176-92.

${ }_{9 *}$ Force, Whiston, 113-19.

${ }^{99}$ For Priestly see C. Garrett, 'Joseph Priestly, the Millennium and the French Revolution', Journal of the History of Ideas, XXXIV (1973) 51-66, and J. Fruchtman, 'Joseph Priestly and Early English Zionism', Enlightenment and Dissent, no. 2 (1983) 39-46. For an example of an Irish Arian response to the Revolution see W. D. Baillie, 'The Reverend Samuel Barber 1738-1811: National Volunteer and United Irishman', Haire et al., Challenge and Conflict, 72-95.

100) Clayton, Vindication, [I], 28. 
Christ to come', whereas the former was into belief 'of the Messiah, as come' ${ }^{101}$ That Clayton saw no great distinction between the faith of Jews and that of Christians, other than in the Christian identification of the Messiah, is apparent in his apologetic addressed to Jews, which did not trouble much over matters which might have been expected to warrant discussion, such as the doctrine of the atonement. ${ }^{102}$ This, though, is hardly surprising in the light of the soteriology he later expressed. ${ }^{103}$ Clayton lacked the emotional identification expressed by other non-Trinitarians with 'Jehovah's ancient and modern witnesses the Jews', who suffered with themselves 'all that intollerant establishments could inflict' in consequence of their defence of the unity of the Godhead. ${ }^{104}$ However, he failed to draw any fundamental distinction between Christian and Jewish belief and his statement about the content of the latter can well be taken as a statement about the content of the former. For Clayton, Christianity preached morality, about which, in fact, he did not choose to write much, and excited messianic expectation, about which his writings were constantly concerned.

Clayton's writings can quite truthfully be depicted, as they have been above, simply as apologetic for immanentist supernaturalism in Christianity. But the more precise description is of a body of works springing from the Protestant millenarian tradition. It is his Dissertation on Prophecy, his calculation of the time of the coming of the Messiah by means of a comparison of scripural prophecy with the histories of the Jews and the Papal Anti-Christ, which should be taken as the starting point for an understanding of Clayton's thought. The purpose of the The Chronology of the Hebrew Bible Vindicated, to be now quite precise, was to reject the claim of Arthur Bedford, that there was a longer interval between the creation and the incarnation than was thought. ${ }^{105}$ The point was crucial, since confirmation of the calculation of the date of the Second Coming was derived from a prisca theologia tradition, recorded in 'the Age of Zoroaster'

101 [Clayton] and Penn, Letters concerning Baptism, 18.

102 There is, though, some treatment of this. Robert [Clayton], An Impartial Enquiry into the Time of the Coming of Messiah; in a second letter ... to an eminent Jew (London 1751) 54-60.

${ }_{103}$ Clayton, Vindication, III, pp. 186-232.

${ }^{104}$ Palmer, T[homas] Fyshe, An Attempt to Refute a Sermon ... on the Godhead of Jesus Christ (Edinburgh 1792) v-vi. Palmer was a disciple and friend of Priestly, condemned to transportation for involvement in the revolutionary activities of the 1790 s in Scotland. See [Anon.], Memoirs and Trials of the Political Martyrs of Scotland (Edinburgh, 1837) 19-21.

${ }_{104}$ [Clayton], Chronology of the Hebrew Bible, see esp. 1-37. 
and in the Talmud, which spoke of anni mundi. ${ }^{106}$ The attack from Bolingbroke on millenarian belief, which induced Clayton to begin the series which ended in the public declaration of his Arianism, was a good deal wider than Bedford's, denying the possibility of deriving any system of chronology from the scriptures. That the doctrinal - as opposed to moral - content of his religion consisted of little more than an eschatology led him naturally into addressing the Jews, to whom he attributed the same stance and whose conversion was 'seen as the crucial pre-Millenial event. ${ }^{107}$ Finally, since his expectation was, one is inclined to say, maintained as much by enthusiasm for the fall of the Roman harlot as for the triumphant return of Christ, his zeal for the root and branch reform of religion which Arianism constituted was equally natural.

If Clayton's religion, under the larger designation of immanentist supernaturalism, showed marked attenuation, the same trend can be traced in his specifically millenarian beliefs. As lesser manifestations of the supernatural were pushed into the remote past, so the millennial reign of Christ was pushed into the remote future. The millenarian tradition in which Clayton wrote was uniform in claiming that the Second Coming was to take place after the Anti-Christ's reign of 1,260 years, which period was also the 'time of the gentiles', mentioned in Luke XXI.24 and interpreted as the era of Jewish exile. The figure was arrived at from the reference in Daniel VII.25 to 'a time and times and half a time', i.e. three and a half years or 1260 days, and from the dependent text, Revelation XI.2. The claim that the days were to be understood as years was supported by Ezechiel IV. 6. The difficulty lay in knowing when the reign of the Anti-Christ had begun. Clayton accepted Newton's view on this. It took place

when the Pope of Rome had so far shaked off his Dependence on the Emperor, as to change the Manner of Dating his Bulls and Epistles from the customary Form of the Year of the Reign of each Emperor, to that of Dating them by the Years of his own being in the Popedom. Which remarkable Event came to pass A.D. 755. ${ }^{108}$

His acceptance was somewhat hesitant: this was but an opinion. ${ }^{109}$ But the prophecy which dated the Second Coming by anni mundi

"x. [Clayton], A Dissertation on Prophecy ... with an explanation of the Revelation of St. John (Dublin 1749) 129-32. [Clayton], Enquiry, 32-33 and 37-41.

${ }^{107}$ Popkin, ed., Millenariantsm and Messianism, 6. See Christopher Hill's article,

" "Till the conversion of the Jews"' in this volume, 12-36.

${ }_{108}^{10}$ [Clayton], Enquiry, 31.

${ }_{109}$ Ibid., 35. 
confirmed that Newton was, in any case, approximately right. The millennium was safely two and a half centuries away.

Clayton appears to have thought that this postponement alone was insufficient to banish the dangerous enthusiasm associated with millenarianism. He emphasised that no sudden overthrow of the existing order was to be expected: the events predicted in Revelation would take place over a period of many years ${ }^{110}$ and would be a continuation of trends already visible."' Further, in describing the millennium, he emphasised that any anticipation of 'the Enjoyments of this World', of 'sensual and earthly Pleasures' was inappropriate. ${ }^{112}$ What was to be expected was 'a spiritual Kingdom, the Happiness of which will consist in Righteousness and Peace, and such other Joys as may arise from ... restraining, rather than indulging, our Passions.' 113

At first glance, a justification for giving serious attention to the work of Robert Clayton seems difficult. By no means universally esteemed in his own time, he also failed to excercise influence in a later one. However, he hardly deserves the reputation which he then acquired, that of the eccentric propagator of 'old heresies' - to borrow the phrase of Warburton. True, the mechanistic interpretation of Newton was eventually to be defined as orthodoxy and the vision of a world 'replete with spirits' which the Cambridge Platonists and Clayton had seen was to be banished as heresy. But it is important for the understanding of the eighteenth-century mind to recall that in Clayton's time it was not yet clearly heresy. It can be added that even when this vision did become heresy it was not without influence, well into the nineteenth century.

Similar observations may be made about Clayton's Arianism. Of course, if Newman was right and liberalism was but Arianism under another name, its banishment as heresy as a consequence of the rise of Evangelicalism and other religious phenomena of the early nineteenth century was hardly very effective. Still, the effort to banish it was made by Evangelicals like Henry Cooke, with enduring historical importance for Irish Protestantism, as well as Newman, with enduring consequences in both ecclesiastical and intellectual history.

110 [Clayton], Dissertation on Prophecy, 225-9.

"1' [Clayton], Enquiry, 32.

112 [Clayton], Dissertation on Prophecy, 216-25

"1" [Clayton], Impartial Enquiry, 66. 
If the importance of Arianism to such men is not grasped, their minds, and indeed the mind of the early nineteenth-century church in the British Isles as a whole, are far from well understood. The present study should at least have made it clear that their concern with Arianism was by no means a personal peculiarity: it was a reflection of the dominant features of religious thought in the immmediately preceding period. More, however, may be said. An appreciation of the point made in the second section of this study about the relationship of Arianism to the English Enlightenment clarifies the intellectual identity of Newman as a Counter-Enlightenment thinker, comparable to, if more important than, the guides of Restoration Europe, such as de Maistre or de Bonald in France. Valerie Pitt's hostile observation that 'it sometimes seems that Newman, Keble and all their bright young men were unable to make the transition from the seventeenth to the eighteenth century, let alone into their own restless times' 114 in fact reveals the significance of Newman very well. His work constituted a profound criticism of the Enlightenment in its English form. Nor, in view of the observations made in the third part of this study, about the continuities between the Puritan tradition and Arianism, does it seem particularly surprising that Newman's critique of modernity emerged from a revival of High Churchmanship. This had indeed always constituted the foundation and substantial structure of the English CounterEnlightenment.

\section{A denial of authorship}

From the time of its publication in 1750 until 1784, the attribution of the Essay on Spirit to Clayton was general and unchallenged. It lost him the see of Tuam; but, 'mortified' as he and his wife were by this, he took no step to have his authorship denied. Even those on intimate terms with the bishop, like Mary Delany, expressed no doubts. ${ }^{115}$ No one else was mentioned as the author, until Andrew Kippis, in his article on Clayton for the Biographia Britannica, repeated as true an improbable sounding tale which he had obtained from his chief source on Clayton, Dr. Thomas Campbell, a clergyman of the diocese of Clogher, who in turn had received it from

$11+$ V. Pitt, 'Demythologising Newman', D. Nicholls and F. Kerr, eds, John Henry Newman: Reason, Rhetoric and Romanticism (Bedminster and Carbondale 1991) 1327.

${ }^{115}$ Mary Delany to Anne Dewes, 22 Feb. 1752 and 11 April 1752, Day, ed., Letters from Georgian Ireland, 282 and 93. 
Thomas Barnard, who, when Kippis wrote, was the bishop of Killaloe. According to this

The real author of it was a young clergyman in our Prelate's diocese, who shewed the manuscript to his Lordship, and, for reasons which may be easily conceived, expressed his fear of venturing to print it in his own name. The Bishop, with that romantic generosity that marked his character, readily took the matter upon himself; and determined to sustain all the obloquy that might arise from the publication. ${ }^{116}$

Any substantial acquaintance with Clayton's writings as a whole, with which the Essay is manifestly uniform, would have made clear that this story simply could not be taken seriously. However, perhaps simply because it was repeated, ${ }^{117}$ Bishop Reeves took the matter seriously and turned up one slight piece of manuscript evidence against Clayton's authorship, though this also confirmed that Clayton was at least involved in the production of the work. ${ }^{18}$ The matter continues to be mentioned and thus there is some point in attempting an explanation of the story's origin.

Barnard, it ought to be noted, was something less than a disinterested informant. He was the husband of Clayton's niece and had inherited 'the greatest share of his fortune'. ${ }^{119}$ In later years he was proud enough of his relative by marriage and benefactor to present to Trinity College the bust of him that is still to be seen there. ${ }^{120}$ As for Campbell, he seems to have done little to ensure that the information he passed on was accurate. ${ }^{\mid 21}$ Later though, he stated, in print, that Clayton was the author. ${ }^{122}$ For Kippis, the story fitted well with his article's depiction of Clayton as the talented and enlightened scholar who suffered a persecution, which at length brought about

116 Kippis et al., eds, Biographia Britannica, III, 623.

${ }_{117}$ See, for example, Clayton, Bishop Clayton on the Creeds, 34.

118 T.C.D., MS. 1142, 55-65 and 83-89.

119 Kippis et al., eds, op. cit., 628.

120 A. Crookshank and D. Webb, Paintings and Sculptures in Trinity College Dublin (Dublin 1990) 36.

${ }^{21}$ Kippis's article is littered with factual errors from the beginning, where Clayton is said to have been born in Dublin, the son of the 'minister of St. Michael's'. See Kippis et al., eds, op. cit., III, 620. His matriculation record in Trinity College, Dublin, shows him to have been born in England and his father was in fact the prebendary of St. Michan's. See T.C.D., MS 1142, 95. Though the article sought primarily to give an account of the bishop's writings, even here there was confusion. Since the translation of Clayton's Chronology of the Hebrew Bible had been published under the title Introduction a l'histoire des Juifs (Leiden 1752, the author's name given as 'Cleyton'), an English work with this title was invented. See Kippis et al., eds, op. cit., III, 621. Some of these errors may, of course, be attributable to Kippis rather than Campbell.

${ }_{122}$ Winnett, 'An Irish Heretic Bishop', 314. 
his death, at the hands of the obscurantist orthodox. In this instance, he lost his just preferment on account of a book which he had not even written. ${ }^{123}$

Allowing that Barnard had some interest in vindicating his relative to a more orthodox age, it may still appear odd that he should simply lie, as it may appear, so pointlessly and so foolishly inviting disbelief. After all, that Clayton was an Arian could not be disputed and it was his published works, and not mere rumour which indicated him as the author of the Essay. However, one should recall that some twenty five years after his death, Clayton's works were unread - perhaps even by Barnard - and his name recalled only in connection with the work which had created the greatest scandal. Anyway, the story was, in fact, believed. If there is still an unwillingness to attribute plain mendacity to such a senior ecclesiastic as Barnard, it might be suggested that his story was not simply his ex nihilo creation. One might speculate that it recorded some memory that Clayton received help from one of his clergy in the composition of the Essay; that it was not without some, albeit slight foundation.'

${ }^{123}$ Kippis et al., eds, op. cit., III, 623-24 and 627. Note also Kippıs's reference to another Arian bishop, 'the excellent Dr. Rundle, who had been unjustly and malignantly persecuted in England'. Ibid., 621. Rundle's 'persecution' resulted in him being given the richest bishopric in Ireland, Derry, instead of Gloucester. 